
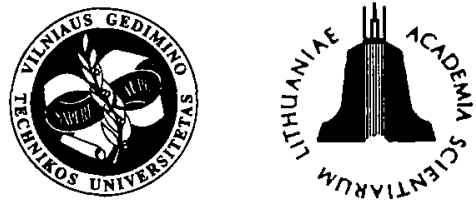

ISSN 1392-3730

JOURNAL OF CIVIL ENGINEERING AND MANAGEMENT

http:/www.vtu. It/english/editions

2003, Vol IX, No 1. 25-35

\title{
INFLUENCE OF HOMOGENEITY OF MINERAL MATERIALS' GRADING AND DOSING ERRORS ON THE STABILITY OF ASPHALT CONCRETE MIXTURE COMPOSITION
}

\author{
Henrikas Sivilevičius \\ Dept of Transport Technological Equipment, Vilnius Gediminas Technical University, \\ Plytines g. 27,LT-2016 Vilnius, Lithuania.E-mail: henrikas@ti.vtu.lt,
}

Received 21 Oct 2002; accepted 09 Jan 2003

\begin{abstract}
Errors of optimal composition asphalt concrete mixture designed in the laboratory and their importance for road construction are investigated. After the analysis of asphalt concrete production according to the traditional technology, factors influencing its structure, characteristics and quality are systematised. Mathematical models of dependence of medium quadratic deviations of siftings of finite dosed mineral materials through control sieves on the means of siftings are estimated by a regressive analysis. Variations of grading of hot fractions $0-5 \mathrm{~mm}$ and $5-15 \mathrm{~mm}$ as well as cold mineral powder sieved through technological sieves of mixing equipment and influence of errors of dosing these mineral materials in the produced mixture on the stability of quantity of containing mineral components (crushed stone, sand and mineral filler) are identified. The main trends of asphalt concrete structure and handling of its equipment methods improvement are presented.
\end{abstract}

Keywords: asphalt concrete mixture, production technology, quality improvement, composition stability, statistical analysis, segregation, errors of dosing.

\section{Introduction}

The purpose and functions of asphalt concrete components were identified and the methods of its mixture composition created by Sacharov P. V. (1913), Edwards L. N. (1918), Ebberts A. R. (1928), Vichert P. (1929), Le Gavrijan (1921), Neumann (1929), Wilson G. Harger and Edmond A. Bonney (1927) [1, 2] etc. The principles of asphalt concrete structure formation developed by them have been constantly improved by applying the novelties of rapidly developing science. Researchers and engineers from various countries have been working in this promising area. Rapid progress of equipment and technologies enabled to implement theoretical knowledge in practice and assess its applicability. Having studied the theoretical assumptions of asphalt concrete mixture formation from mineral materials consisting of various sizes of grains and organic binder (tar, bitumen), industrial production and mechanised laying technologies were developed [3].

Studies were conducted to identify how asphalt concrete functions in the road pavement when it is influenced by climatic conditions and loads of vehicle wheels, how characteristics of materials used for its production and structure change. The most important findings were published in the United Kingdom [1, 4], USA [5-8], Canada [9-12], Saudi Arabia [13], Jordan and the United
Arab Emirates [14], Korea [8, 12], Russia [15-27), Byelorussia $[28,29]$ as well as other countries.

Lithuanian researchers have been working in the field of increasing the durability of asphalt concrete pavement as well [30-33]. Data received from research show that characteristics, structure, and insufficient durability of asphalt concrete depend on the quality of the asphalt concrete mixture used. Therefore, thorough investigations have been carried out. The strength of asphalt concrete is influenced not only by external and internal factors, road pavement base structure, the thickness of layers, but also by the mixture characteristics which are formed when producing it in a plant.

The influence of stochastic parameters of the process of asphalt concrete production on the product quality in the mixing plant of the old type was studied by $\mathrm{S}$. Rokas [30] and V. A. Borisov [34] in 1975-77. These researchers as well as their disciples $[32,33]$ identified the actual values of materials characteristics and technological parameters of asphalt concrete mixture production and its composition as well as deviations from physical-mechanical indices. They proved that the values of deviations shall be reduced and actual deviations shall be taken into account when handling the technological process of asphalt concrete mixture. However, the technological causes influencing the quality of asphalt concrete mixture production due to the complexity of spe- 
cial experiments requiring to interfere with the process of production and produce some products of a bad quality as well as a lack of theoretical knowledge have not been studied thoroughly yet.

During the last 25 years the construction and handling systems of asphalt concrete mixing plants has been considerably improved and technological accuracy as well as productivity have been increased. They have become more universal, air pollution has been reduced due to less emmisions, which requires different and modern treatment of this area of road construction. Scientific as well as equipment novelties implemented in the new generation modern asphalt concrete mixing plants make their users to improve their qualification and to use the characteristics of technological equipment in the most efficient way.

Designers and manufacturers of asphalt concrete mixing plants shall know how old and new equipment functions (if the products produced in them suit for road pavement construction). The construction of new computerized asphalt concrete mixing plants differs from the older equipment; however, the most technological processes applying in them have the same kinetics and are the same in essence. Different systems of parameters' control and handling, the effectiveness of which depends on the operators' work, are used in them. The latest research shows [35] that the technological process of asphalt concrete mixture production should be improved since it means improving the quality of the product.

Most producers believe that when the technological process of modern asphalt concrete mixing plant is handled by a computer, good results are always achieved. Such categoric statement of asphalt concrete mixing plants' owners (producers of asphalt concrete mixtures) can be understood as a justification advertisement. Meanwhile some specialists carrying out the functions of the customers who purchase and use asphalt concrete mixture for constructing roads of national importance agree with them as well. The quality of asphalt concrete mixture production is higher in a modern computerised asphalt concrete mixing plant providing that the operator (a human being) handling the technological process carries out his work properly. A computer does not solve all problems of the production quality.

Operators and production managers handling complex technological processes must understand the peculiarities of asphalt concrete mixture production in order to use the capabilities of asphalt concrete mixing plant construction to its maximum. Even if asphalt concrete mixing plants of the highest quality are used, but factors influencing the quality of asphalt concrete mixture production are not taken into account, separate operations as well as the whole technological process of production cannot be handled so that the product complied with the requirements set by the client.

If it is not possible to replace the old asphalt concrete mixing plant by modern technological equipment (mostly due to a high price of the modern asphalt concrete mixing plant), the work shall be carried out so that the requirements for the quality of the product were met. To use the technical capabilities of the maintained asphalt concrete mixing plant's construction to its maximum, the influence of all or at least the most important technological factors of asphalt concrete mixture production on its quality shall be known. Having identified the influence of such factors on the quality of asphalt concrete mixture production, the construction, work regime and handling method of equipment could be improved.

The aim of this study is to identify technological factors of asphalt concrete mixture production which mostly influence the homogeneity of its mineral components' grading and to present theoretical principles as well as practical methods for increasing the same quality of products.

\section{Model of asphalt concrete mixture production tech- nological operations}

The structure of asphalt concrete is formed when its mixture is produced in an asphalt concrete mixing plant and when laying and compacting it on the road pavement. It shall have characteristics which are obtained during technological operations (Table 1). The parameters of these operations influence obtaining the required characteristics of asphalt concrete mixture or asphalt concrete.

The optimal ratio of original cold mineral materials mass selected at the laboratory (their quantity in percent) shall be maintained in the designed asphalt concrete mixture when producing it in an asphalt concrete mixing plant. Laboratory operations of weighing, heating, and mixing materials carried out in small quantities (portions of up to several kilograms) differ considerably from these operations which are carried out at the asphalt concrete mixture base. When producing asphalt concrete mixture mineral materials and bitumen are supplied to asphalt concrete mixing plants in dosed flows from the storehouses according to the fixed intenssity (from a few, several to several dozens tons per hour), where their characteristics are changed in a certain sequence.

When storing mineral materials supplied to the asphalt concrete base territory, they change their characteristics: accumulate water, get cold, segregate, adhere, become impure, and the activity of crushed grains surface decreases. Therefore, they have to be properly processed before their application to obtain the asphalt concrete mixture of optimal composition, structure and characteristics. They shall comply with the requirements specified not only in norms [36-38] but also technological specifications enabling to use these materials in the asphalt concrete mixture under production. Crushed stone $(\mathrm{Cs})$, crushed gravel $(\mathrm{Cg})$, siftings $(\mathrm{Si})$, and natural sand (Ns) shall be dry, hot and homogeneous; mineral powder (Mp) shall be dry and not compressed; bitumen $(B)$ shall be hot, liquid and waterfree; recycled 
Table 1. Factors influencing the asphalt concrete structure and characteristics

\begin{tabular}{|l|l|}
\hline \multicolumn{1}{|c|}{$\begin{array}{c}\text { Characteristics and } \\
\text { structure }\end{array}$} & \multicolumn{1}{c|}{$\begin{array}{c}\text { Technological operation } \\
\text { enabling to obtain } \\
\text { characteristics }\end{array}$} \\
\hline $\begin{array}{l}\text { 1. Optimal averagc } \\
\text { quantity of all } \\
\text { components in asphalt } \\
\text { concrete mixture }\end{array}$ & $\begin{array}{l}\text { By using intial and finite dosed } \\
\text { mineral materials of the required } \\
\text { grading. By dosing mineral } \\
\text { materials and bitumen accurately. }\end{array}$ \\
\hline $\begin{array}{l}\text { 2. High homogeneity of } \\
\text { asphalt concrete } \\
\text { mixture grading }\end{array}$ & $\begin{array}{l}\text { By dosing non-segregated mineral } \\
\text { materials of stable grading, by } \\
\text { dosing portions of stable mass. }\end{array}$ \\
\hline $\begin{array}{l}\text { 3. Uniform distribution } \\
\text { of components in a } \\
\text { batch of asphalt } \\
\text { concrete mixture }\end{array}$ & $\begin{array}{l}\text { By mixing dosed mineral } \\
\text { materials and bitumen in batches } \\
\text { completely. }\end{array}$ \\
\hline $\begin{array}{l}\text { 4. All grains covered by } \\
\text { a solid film of } \\
\text { structurised bitumen }\end{array}$ & $\begin{array}{l}\text { By dosing optimal quantity of } \\
\text { bitumen. By mixing all materials } \\
\text { rather intensively and for a long } \\
\text { time. }\end{array}$ \\
\hline $\begin{array}{l}\text { 5. High bitumen } \\
\text { adhesion forces to } \\
\text { grains }\end{array}$ & $\begin{array}{l}\text { By using waterfree materials of } \\
\text { required temperature. By applying } \\
\text { rational sequence of connecting } \\
\text { dosed materials in mixing } \\
\text { products: traditional, two-stage or } \\
\text { separately consistent technology. } \\
\text { By using additive activating } \\
\text { surface (AAS). By using the } \\
\text { higher activity of the surface of } \\
\text { new crushed mineral materials. }\end{array}$ \\
\hline $\begin{array}{l}\text { By storing the produced asphalt } \\
\text { concrete mixture for a short time } \\
\text { by protecting it from contact with } \\
\text { air oxygen. By not preventing the } \\
\text { segregation of asphalt concrete } \\
\text { mixture. }\end{array}$ \\
\hline $\begin{array}{l}\text { concrete mixture from an the } \\
\text { cooling and } \\
\text { segregation as well as } \\
\text { bitumen from oxidation } \\
\text { 7. Compactness of } \\
\text { mineral component } \\
\text { grains in asphalt }\end{array}$ & $\begin{array}{l}\text { By using appropriate rollers, } \\
\text { compacting technology, and } \\
\text { taking into account weather } \\
\text { conditions. }\end{array}$ \\
\hline
\end{tabular}

asphalt concrete (Rac) shall be dry, hot, containing liquid old bitumen and homogeneous (Fig 1). These main technological characteristics of mineral materials and organic binder are obtained by properly storing them in an asphalt concrete base and preparing in asphalt concrete mixing plant.

In Lithuania as well as other European countries asphalt concrete mixtures are usually produced in sampling action (cyclic, discrete, batching) asphalt concrete mixing plants operating according to the traditional technology. The interrelation model of the most important preparatory and main operations of this technology (Fig 1) shows that in the beginning continuous and at the end discrete operations are carried out with materials from 4 groups in an asphalt concrete base and a mixing plant. When asphalt concrete mixtures of different types are produced in asphalt concrete mixing plants of various construction, recycled concrete and reclaimed dust (these materials are marked by a dotted line in the model) cannot be used. Then discrete dosing units of these materials are absent or they do not operate.
When producing asphalt concrete mixture, properly prepared cold mineral powder, hot bitumen and cold or hot recycled asphalt concrete are directly transferred to the asphalt concrete mixing plant upon their discrete dosing. Grains of cold crushed stone, siftings, crushed gravel, and natural sand redistribute in asphalt concrete mixing plants and compose completely different mineral materials (3-5 hot fractions and reclaimed dust), which fall into the mixing plant upon their discrete dosing. Dosing errors of finally dosed mineral materials and stability of their grading has considerable impact on the quality of asphalt concrete mixture production according to the traditional technology.

When sieving the mixture of original mineral materials into separate fractions through technological screens of asphalt concrete mixing plant, that these hot materials should be less contaminated with-by-grains and will have more homogeneous grading as original cold materials of similar size. When using original mineral materials contaminated with smaller or only grains larger than those specified in the laboratory project of asphalt concrete mixture composition, their technical specifications, passport, quality certificate, and when the quantity of such as well as standard particles varies at a wide range in the course of time, less contaminated and more homogeneous fractions shall be obtained upon sieving the mixture. When an asphalt concrete mixture is formed of pure hot mineral materials of stable grading, the experimental testing of their quality, control testing of the quantity in asphalt concrete mixture as well as the system of handling the mixture production process are simplified. Therefore, the adjustments of the diverted composition of the produced mixture takes less time and is more accurate. However, research carried out by us showed [39] that hot fractions can be highly impure and not homogeneous.

When applying traditional technology of asphalt concrete mixture production, more expensive, complex asphalt concrete mixing plants shall be used. In asphalt concrete mixing plants in the USA, continuous action asphalt concrete mixing plants of the drum mix type are mostly used $[3,40]$. Such technological equipment has a implified construction, is more dependable and efficient. However, the technological processes of asphalt concrete mixture production occuring in them cannot be stopped frequently during the working shift. It shall be handled by the microprocessor according to software, and the mineral materials for the mixture production shall be pure, with stable grading and non-segregated. Simple construction of such continuous action asphalt concrete mixing plants enables to manufacture mobile asphalt concrete mixing equipment and to use greater amounts of recycled asphalt concrete (up to $40-70 \%$ ) $[41-43]$. However, when using gravitational mixing of materials in a drum mixing plant, proper homogeneity of asphalt concrete mixture is not always obtained. Recently this problem has been solved in the USA by using a new drying-mixing plant with a double drum, in which the internal drum with fixed paddles rotating in the external stationary cyl- 


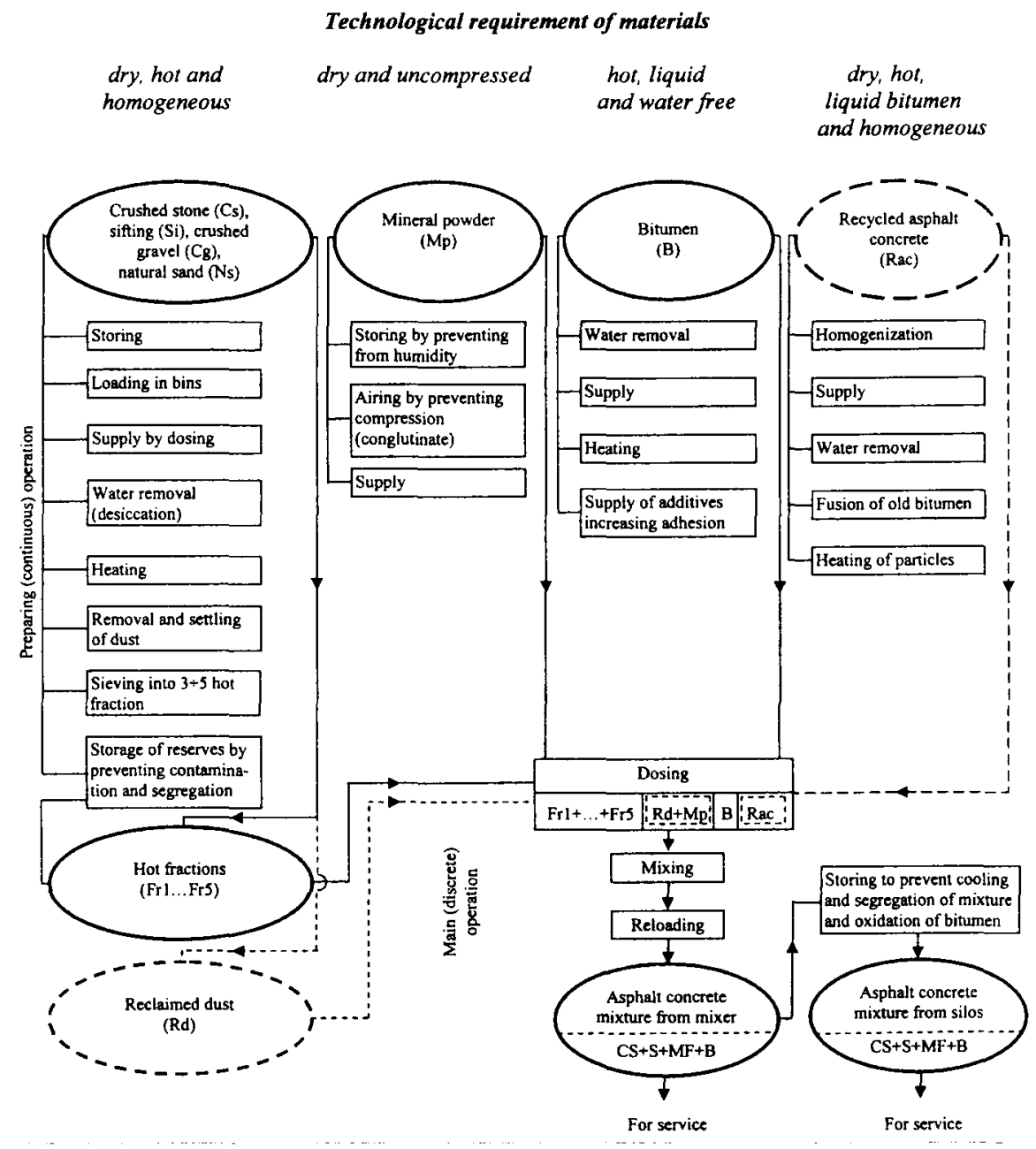

Fig 1. Interrelation model of preparatory and main operations carried out in an asphalt concrete mixing plant of materials used in asphalt concrete mixture production according to the traditional technology

inder (,double-drum mixer" or "Double Barrel" system) enables to mix the components of the mixture [40]. Researchers have invented and producers implemented the latest gravitational mixing systems of continuous action drum asphalt concrete mixing plants Venturi (,Venturi mixer") and triple-drum mixer which enable to produce high a quality mixture.

\section{The quality of hot fractions sieving}

Hot fractions sieved through technological sieves of asphalt concrete mixing plant shall contain only such grains the diameter of which is specified in the instructions. Due to the short duration of dried and heated mixture of continuously dosed original mineral materials' flow movement through technological sieves, imperfect construction of the screening equipment and too high loading with mixture, its shall be divided into hot fractions containing not only standard but also by-grains. Research data [39] on the grading of hot fractions falling from seven asphalt concrete mixing plants bins sections showed that they are contaminated with more than $10 \%$ smaller and larger grains. The average contamination of fractions in separate asphalt concrete mixing plants is not the same and varies at a wide range during a working shift. The hot fraction of $0-5 \mathrm{~mm}$ is contaminated with grains of crushed stone which are larger than $5 \mathrm{~mm}$ on average, $\mu_{i j}=5,8 \%$ (from $0,94 \%$ to $13,72 \%$ ) and with grains of mineral filler smaller than $0,071 \mathrm{~mm}: \mu_{i j}=9,8 \%$ (from $6,22 \%$ to $13,37 \%$ ) (Table 2). In hot fraction of $5-15 \mathrm{~mm}$, there are grains smaller than $5 \mathrm{~mm}$ are on average $\mu_{i j}=16,8 \%$ (from $4,59 \%$ to $32,76 \%$ ). In grains smaller than $5 \mathrm{~mm}$ on average, there are $\mu_{i j}=1,4 \%$ mineral filler (from $0,20 \%$ to $3,00 \%$ ), the actual quantity of which shall be known and taken into account when adjusting the dosing unit.

Studies conducted in the USA [44] in 1967 identified that the highest average standard deviation $\sigma_{\max }$ of mass in percent of the total siftings of any aggregate percentage passing control (laboratory) sieves distrubutes according to a binomial law:

$$
\sigma_{\max }=\sqrt{\mu(100-\mu)}
$$

$\mu$ - general mean of siftings mass percentage passing laboratory (control) sieve in \%. 
Table 2. Average statistical characteristics of asphalt concrete mixture mineral components quantity in hot fractions of $0-5 \mathrm{~mm}$ and $5-15 \mathrm{~mm}$ as well as cold mineral powder sieved through technological screens of asphalt concrete mixing plants

\begin{tabular}{|c|c|c|c|c|c|}
\hline \multirow{2}{*}{$\begin{array}{c}\text { Finally dosed } \\
\text { mineral material } \\
j=1, \ldots, m\end{array}$} & \multirow{2}{*}{$\begin{array}{c}\text { Arithmetical } \\
\text { mean and } \\
\text { average standard } \\
\text { deviation }\end{array}$} & \multicolumn{3}{|c|}{$\begin{array}{l}\text { Quantity of mineral component in \% in mineral material } \\
\qquad i=1, \ldots, k\end{array}$} & \multirow{2}{*}{$\begin{array}{c}\text { Dosing error } \\
\text { (variation } \\
\text { coefficient of } \\
\text { dosing masses) } \\
V_{q j} \%\end{array}$} \\
\hline & & $\begin{array}{l}\text { Crushed stone } \\
\text { (particles larger } \\
\text { than } 5 \mathrm{~mm} \text { ) }\end{array}$ & $\begin{array}{l}\text { Sand particles } \\
(5-0,071 \mathrm{~mm})\end{array}$ & $\begin{array}{l}\text { Mineral filler } \\
\text { (particles finer than } \\
0,071 \mathrm{~mm} \text { ) }\end{array}$ & \\
\hline \multirow{2}{*}{$\begin{array}{l}\text { Hot fraction } \\
0-5 \mathrm{~mm}\end{array}$} & $\mu_{i j}$ & 5.8 & 84.4 & 9.8 & \multirow[b]{2}{*}{3,8} \\
\hline & $\sigma_{\mu i j}$ & 3,05 & $3,61 *$ & 1,90 & \\
\hline \multirow{2}{*}{$\begin{array}{l}\text { Hot fraction } \\
5-15 \mathrm{~mm}\end{array}$} & $\mu_{i j}$ & 83,2 & 15.4 & 1,4 & \multirow[b]{2}{*}{6,4} \\
\hline & $\sigma_{\mu i j}$ & 3,42 & $3,46^{*}$ & 0,36 & \\
\hline \multirow{2}{*}{$\begin{array}{l}\text { Cold mineral } \\
\text { powder }\end{array}$} & $\mu_{i j}$ & 0 & 18,1 & 81.9 & \multirow[b]{2}{*}{20,3} \\
\hline & $\sigma_{\mu i j}$ & 0 & & 2,00 & \\
\hline
\end{tabular}

* $\sigma_{\mu i j}$ - value obtained not from the equation of regression but as a mean of seven asphalt concrete mixing plants $\sigma_{5-0,07 !}$

In some maximally segregated mineral materials $\sigma_{\max }=50 \%$ grains make up half of the whole material, ie $\mu=50 \%$. When using this dependence, variation of mineral materials' grading of various size can be compared.

Average standard deviations showing the variation of siftings of mineral materials percentage passing control sieves used in grains and identified during experiments when a samples are tested are considerably smaller than theoretical $\sigma_{\max }$ since their actual segregation is always less than maximum. The values of empirical average standard deviation $\hat{S}_{F r 0-5}$ of hot fractions $0-5 \mathrm{~mm}$ siftings passing technological sieves screened through seven asphalt concrete mixing plants control identified from 337 local samples vary according to the following equation of regression

$$
\hat{S}_{\text {Fr } 0-5}=\sqrt{6,07 \cdot 10^{-6} X^{2,478}(100-X)^{1,698}},
$$

$X$ - empirical mean of siftings' mass passing control sieves in $\%$.

This characteristics of stability of hot fractions of 5-15 mm identified from $n=336$ local samples distributes according to the following equation of regression:

$$
\hat{S}_{\text {Fr } 5-15}=\sqrt{7,28 \cdot 10^{-5} X^{1,928}(100-X)^{1,481}} \text {. }
$$

In cold mineral powder which does not segregate and does not change its characteristics when getting into the dosing unit due to their fine size, the average standard deviation of siftings passing control sieves is less than of hot fractions and shall be calculated according to the following formula $(n=144)$ :

$$
\hat{S}_{M p}=\sqrt{9,84 \cdot 10^{-6} X^{2,072}(100-X)^{1,308}} .
$$

Equations of regression $(2,3,4)$ obtained from a large number of local samples $n$ and having multi-criterion correlation coefficients $R^{2}$ (correlation ratios $\eta$ ) the numerical values of which are equal to $0,980,0,955$ and 0,982 , which is close to 1 , are dependable. Due to this general average standard deviation $\sigma_{\mu i j}$ (providing $\hat{S}_{i j}=\sigma_{\mu i j}$ ) of any quantity of grains in finally dosed mineral materials (mineral component) can be calculated rather precisely. Values $\sigma_{\mu i j}$ calculated from equations of regression according to values $\mu_{i j}$, presented in Table 2 , were used when identifying the influence of variations of these mineral materials on the variation of mineral components quantity in the produced asphalt concrete mixture.

\section{Technological factors influencing the variation of asphalt concrete mixture components quantity}

Homogeneity (variability) of asphalt concrete mixture is demonstrated through average standard deviations $\sigma_{i}$ of $i$ components quantity contained in it (bitumen $\mathrm{B}$, mineral filler $-\mathrm{MF}$, sand $-\mathrm{S}$, crushed stone - $\mathrm{CS}$ ). These values of homogeneity characteristics for separate components are identified by taking local samples of produced asphalt concrete mixture, by extracting bitumen from them and sieving the mineral part through control sieves. Value $\sigma_{i}$ cannot be identified by any other method. Therefore, complete variance $\sigma_{i}^{2}$ of each component is made up of a number of factors the most important of which are selection and testing methods of samples as well as errors of technological process of production. To assess the quality of materials, methods of disperse analysis were used by foreign [44, 45] and Lithuanian researchers $[30,39]$. Complete variance $\sigma_{i}^{2}$ of the mineral component quantity in the batch of asphalt concrete mixture (products produced during the working shift) shall be calculated according to the following formula

$$
\sigma_{i}^{2}=\sigma_{M i}^{2}+\sigma_{B i}^{2}+\sigma_{G i}^{2},
$$


$\sigma_{M i}^{2}$ - variance of asphalt concrete mixture $i$ mineral component quantity which depends on the methodology of sample selection in $\%, \sigma_{B i}^{2}-$ dispersion which depends on the errors of sample testing in $\% ; \sigma_{G i}^{2}$ - variance which depends on the accuracy and stability of technological operations in the production of mixture in an asphalt concrete mixing plant in \% (Fig 2).

Research [30] showed that variance $\sigma_{G i}^{2}$ makes up as much as $65-73 \%$ of the total quantity of mineral component in asphalt concrete mixture of variance $\sigma_{i}^{2}$ value. On average, it can be stated that

$$
\sigma_{G i}^{2}=0,69 \sigma_{i}^{2}
$$

another part of dispersion $\sigma_{i}^{2}\left(0,31 \sigma_{i}^{2}\right)$ is made up of sample selection and errors of their testing.

When using standard sample taking methodology, equipment of their extraction, sieving, weighing as well as other laboratory equipment when testing samples following the sequence specified in standards and not making mistakes, values $\sigma_{M i}^{2}$ and $\sigma_{B i}^{2}$ are constant, ie $\sigma_{M i}^{2}+\sigma_{B i}^{2}=\sigma_{E i}^{2}=$ const. Technological factors of asphalt concrete mixture production of various asphalt concrete mixing plants vary. Values $\sigma_{G i}^{2}$ of imperfect technically damaged asphalt concrete mixing plant with outdated construction are higher than those of perfect computerised technological equipment.

If factors influencing on $i$ component quantity $(i=1, \ldots, k)$ variance $\sigma_{G i}^{2}$ value and their importance are known, asphalt concrete mixing plants could be purposefully improved as well as parameters of processes occurring in them can be optimised and rational handling methods can be developed to approximate values $\sigma_{G i}^{2}$ to $\sigma_{G i \min }^{2}$ or as much as to 0 .

Value of variance $\sigma_{G i}^{2}$ mostly depends on mineral materials such as hot fractions, stability of cold mineral powder and reclaimed dust grading used in asphalt concrete mixture production (values $\sigma_{g . s . i j}^{2}$ ) and their dosing errors (values $\sigma_{d . k . i j}^{2}$ ). Its actual value for sampling action (discrete, batch-tipe hot-mix) asphalt concrete mixing plant producing a mixture according to the traditional technology can be calculated from the additive model:

$$
\sigma_{G i}^{2}=\sum_{j=1}^{m} \sigma_{g . s . i j}^{2}+\sum_{j=1}^{m} \sigma_{d . k . i j}^{2}, i=1, \ldots, k, j=1, \ldots, m
$$

or

$$
\sigma_{G i}^{2}=\sum_{j=l}^{m}\left(\frac{q_{j} \sigma_{\mu i j}}{Q_{m d}}\right)^{2}+\sum_{j=l}^{m}\left(\frac{q_{j} \mu_{i j} V_{q j}}{100 Q_{m d}}\right)^{2}
$$

$q_{j}-j$ average actual mass of mineral material, $\mathrm{kg}$;

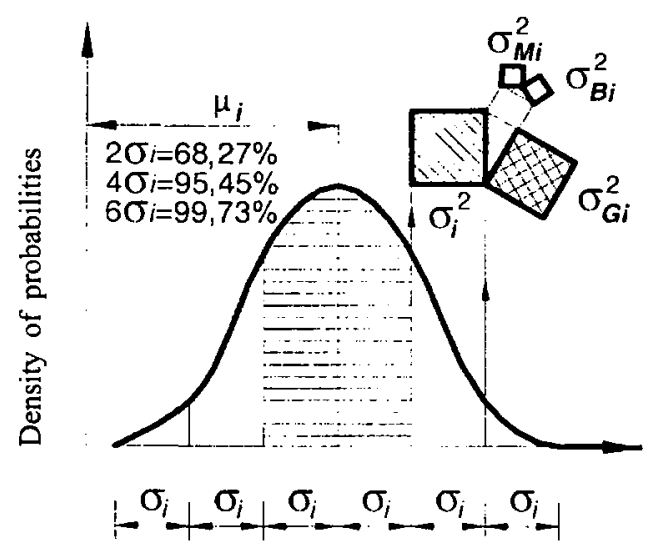

Value of components quantity $x, \%$

Fig 2. Model of conjugation of average standard deviation $\sigma_{i}$ and variance $\sigma_{i}^{2}$ of asphalt concrete mixture portion $i$ - component quantity

$\sigma_{\mu i j}$ - average sdandard deviation of mineral component $i$ in mineral material $j$, masses in $\% ; \mu_{i j}$ - arithmetical mean of mineral component $i$ in mineral material $j$, masses in \%; $V_{q j}$ - dosing error of mineral material $j$, its value being equal to the variation coefficient of its dose mass in \%; $Q_{n d}$ - average mass of mineral part of produced asphalt concrete mixture batch in $\mathrm{kg}$.

Values of variables sizes $\mu_{i j}, \sigma_{\mu i j}$ and $V_{q j}$ presented in mathematical model (8) for concrete asphalt concrete mixing plant are identified by testing finally dosed mineral materials grading and actual statistical characteristics of their doses in advance. They depend on the construction, technical condition, work regime and the handling method of technological equipment. When sizes $\left(q_{j}, Q_{m d}, m\right)$ are given by taking into account the capacity of asphalt concrete mixing plant mixer and project composition (mark) of the mixture and the number of finally dosed materials required for its production, they do not change in the course of time.

When analysing mathematical model (8), value $\sigma_{G i}^{2}$ can be best reduced by decreasing contamination of hot fractions with by-grains (values $\mu_{i j}$ ), variation (values $\sigma_{\mu i j}$ ) of components quantity in finally dosed mineral materials and errors of dosing mineral powder (values $\left.V_{q j}\right)$.

\section{Application of the mathematical model to identify the influence of technological factors}

To identify the influence of actual values of technological factors parameters of asphalt concrete mixture production on the stability of of its mineral part components quantity, values of summands making up variance $\sigma_{G i}^{2}$ were calculated. Values of variables mostly occurring in practice were used, which were obtained from studies carried out earlier [39]. 
When adequacy of model (8) was tested, the following values depending on concrete technological conditions were used:

- Asphalt concrete mixture under production the diameter of its largest particles is $16 \mathrm{~mm}$ (eg $0 / 16 \mathrm{~S}-\mathrm{V}$ ) in sampling action asphalt concrete plant sieving the mixture of hot mineral materials into hot fraction of 0-5 $\mathrm{mm}, 5-15 \mathrm{~mm}$ and $15-35 \mathrm{~mm}$;

- Two finally dosed hot fractions (Fr $0-5 \mathrm{~mm}$ and Fr 5-15 mm) weighed with cold mineral powder in one bin of the dosing equipment $(\mathrm{Mp})$ : at Fr $0-5 \mathrm{~mm}$ dose by adding $\operatorname{Fr} 5-15 \mathrm{~mm}$ dose, and, in the end, Md dose;

- Mass of mineral part of mixture batch is $Q_{m d}=610 \mathrm{~kg}$, bitumen dose is equal to $q_{B}=40 \mathrm{~kg}$; mass of asphalt concrete mixture batch is $Q=650 \mathrm{~kg}$;

- Equal portions of each hot fracion are used $(291 \mathrm{~kg}$ dose Fr 0-5 mm: $47,7 \%$ and $292 \mathrm{~kg}$ dose Fr $5-15 \mathrm{~mm}$ $47,9 \%$ and $27 \mathrm{~kg}$ dose of mineral powder: $4,4 \%$ );

- Errors $V_{q j}$ of materials dosing and quantities $\mu_{i j}$ of components (crushed stone, sand, and mineral filler) in dosed mineral materials and their average standard deviations $\sigma_{\mu i j}$ are taken from Table 2 .

Values of average standard deviations $\sigma_{G i}$ and variance $\sigma_{G i}^{2}$ of crushed stone, sand, and mineral filler quantity in asphalt concrete mixture, depending on technological factors of its production, calculated from mathematical model (8) are presented in Table 3. When compared with actual values $\sigma_{\text {Gif }}^{2}$ obtained during the experiment, the calculated values of variance $\sigma_{G i}^{2}$ comply with actual values: quantity of crushed stone $\sigma_{G 1}^{2}=11,30 \%$, and $\sigma_{G 1 f}^{2}=9,86-17,53 \%$; quantity of sand $\sigma_{G 2}^{2}=8,30 \%$, and $\sigma_{G 2 f}^{2}=9,04-17,60 \%$; quantity of mineral filler $\sigma_{G 3}^{2}=1,44 \%$, and $\sigma_{G 3 f}^{2}=0,60-1,79$. Obtained data enables to state that the constructed model (8) is dependable and shows the influence of separate factors on the stability of mineral part of asphalt concrete mixture.

The influence of separate factors on the stability of asphalt concrete mixture as well as the sequence of error transmission presented in graphs (Fig 3-5) show that variations of crushed stone (CS) quantity in it depend on dosing errors of hot fraction 5-15 mm (57,5\%), stability of its grading $(23,7 \%)$ as well as stability of hot fraction $0-5 \mathrm{~mm}$ grading $(18,7 \%)$. They hardly depend on dosing errors of fraction $0-5 \mathrm{~mm}(0,1 \%)$. Errors of dosing and stability of grading of mineral powder does not influence on the variation crushed stone quantity in asphalt concrete mixture.

Stability of sand (S) quantity in the produced asphalt concrete mixture mostly depends on the stability of grading of fraction $0-5 \mathrm{~mm}$ and fraction $5-15 \mathrm{~mm}$ (35,7\% and 33,1\%, respectively), dosing errors of fraction $0-5 \mathrm{~mm}(28,2 \%)$. It hardly depends on dosing errors of fraction $5-15 \mathrm{~mm}(2,6 \%)$ and almost does not depend on dosing errors and stability of grading of mineral powder $(0,3 \%$ and $0,1 \%$, respectively).

Stability of grading of fraction 0-5 $\mathrm{mm}(57,3 \%)$ and dosing errors of mineral powder) $(37,8 \%)$ have greatest influence on the variation of mineral filler (MF) quantity in asphalt concrete mixture. It hardly depends on dosing errors of fraction $0-5 \mathrm{~mm}(2,2 \%)$ and stability of grading of fraction $5-15 \mathrm{~mm}(2,1 \%)$ and almost

Table 3. Technological factors making up calculated values of average quadratic deviations of asphalt concrete mixture components quantity and their influence in percent

\begin{tabular}{|c|c|c|c|c|c|c|c|c|c|}
\hline \multirow{3}{*}{$\begin{array}{l}\text { Mineral } \\
\text { component of } \\
\text { asphalt } \\
\text { concrete } \\
\text { mixture }\end{array}$} & \multicolumn{6}{|c|}{$\begin{array}{l}\text { Calculated values of separate production factors average standard } \\
\text { deviations } \sigma \text {, variance } \sigma^{2} \text { and their part in percent }\end{array}$} & \multirow{3}{*}{\multicolumn{2}{|c|}{$\begin{array}{c}\text { The } \\
\text { calculated } \\
\text { influence of } \\
\text { all mixture } \\
\text { production } \\
\text { factors on the } \\
\text { values of } \\
\text { mineral } \\
\text { component } \\
\text { quantity } \\
\text { stability } \\
\sigma_{G i} / \sigma_{G i}^{2} \%\end{array}$}} & \multirow{3}{*}{$\begin{array}{l}\text { Variance of } \\
\text { production } \\
\text { errors } \sigma_{G i f}^{2} \\
\text { obtained } \\
\text { from } \\
\text { experimental } \\
\text { data in } \%\end{array}$} \\
\hline & \multicolumn{3}{|c|}{$\begin{array}{l}\text { Due to variation of finally sieved } \\
\text { mineral materials grading }\end{array}$} & \multicolumn{3}{|c|}{$\begin{array}{l}\text { Due to dosing errors of finally sieved } \\
\text { mineral materials }\end{array}$} & & & \\
\hline & $\begin{array}{c}\text { Hot } \\
\text { fraction } \\
0-5 \mathrm{~mm} \\
\sigma_{g .5}^{F r 0-5}\end{array}$ & $\begin{array}{c}\text { Hot } \\
\text { fraction } \\
5-15 \\
\mathrm{~mm} \\
\sigma_{g . s}^{F r 5-15}\end{array}$ & $\begin{array}{c}\text { Cold } \\
\text { mineral } \\
\text { powder } \\
\sigma_{g . s}^{M p}\end{array}$ & $\begin{array}{c}\text { Hot } \\
\text { fraction } \\
0-5 \mathrm{~mm} \\
\sigma_{d . k}^{F r 0-5}\end{array}$ & $\begin{array}{c}\text { Hot } \\
\text { fraction } \\
5-15 \mathrm{~mm} \\
\sigma_{d . k}^{F r 5-15}\end{array}$ & $\begin{array}{c}\text { Cold } \\
\text { mineral } \\
\text { powder } \\
\sigma_{d . k}^{M p}\end{array}$ & & & \\
\hline \multirow{2}{*}{$\begin{array}{l}\text { Crushed stone } \\
\text { (grains larger } \\
\text { than } 5 \mathrm{~mm} \text { ) }\end{array}$} & $1,45 / 2,10$ & $1,64 / 2,69$ & $0 / 0$ & $0,11 / 0,012$ & $2,55 / 6,50$ & $0 / 0$ & \multicolumn{2}{|c|}{$3,36 / 11,30$} & $9,86-17,53$ \\
\hline & 18,7 & 23,7 & 0 & 0,1 & 57,5 & 0 & - & 100 & 100 \\
\hline Sand & $1,72 / 2,96$ & $1,66 / 2,74$ & $0,09 / 0,008$ & $1,53 / 2,34$ & $0,47 / 0,22$ & $0,16 / 0,026$ & \multicolumn{2}{|c|}{$2,88 / 8,30$} & $9,04-17,60$ \\
\hline 0,071 to $5 \mathrm{~mm})$ & 35,7 & 33,1 & 0,1 & 28,2 & 2,6 & 0,3 & - & 100 & 100 \\
\hline Mineral filler & $0,91 / 0,82$ & $0,17 / 0,03$ & $0,09 / 0,008$ & $0,18 / 0,031$ & $0,04 / 0,002$ & $0,74 / 0,541$ & \multicolumn{2}{|c|}{$1,20 / 1,44$} & $0,60-1,79$ \\
\hline $\begin{array}{l}\text { than } \\
0,071 \mathrm{~mm} \text { ) }\end{array}$ & 57,3 & 2.1 & 0,5 & 2,2 & 0,1 & 37,8 & - & 100 & 100 \\
\hline
\end{tabular}




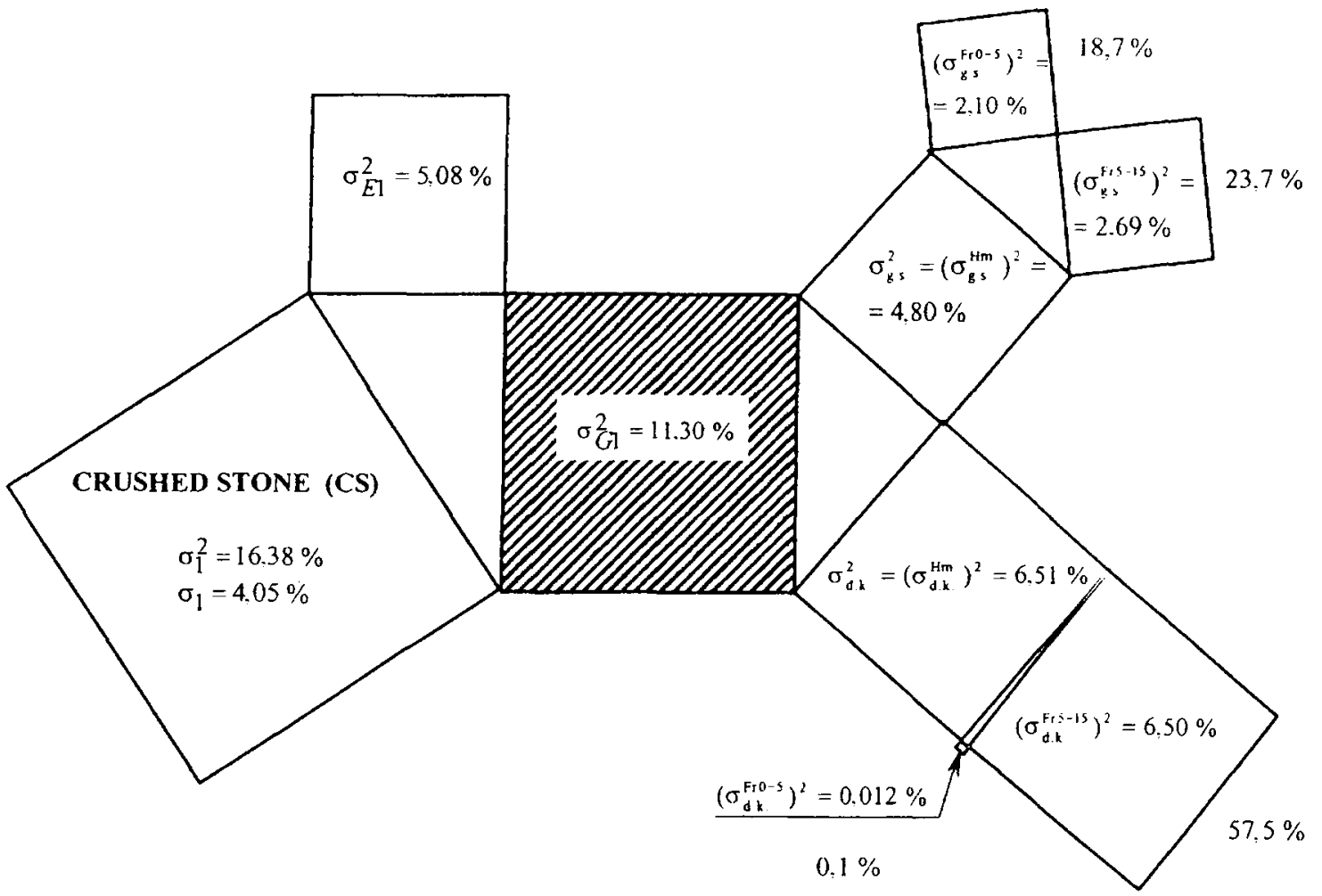

Fig 3. The diagram of technological factors importance influencing the variation of crushed stone (CS) quantity contained in asphalt concrete mixture produced from hot mineral materials of fractions of $0-5 \mathrm{~mm}$ and $5-15 \mathrm{~mm}$ as well as cold mineral powder weighed in the same dosing equipment in sampling action asphalt concrete mixing plant

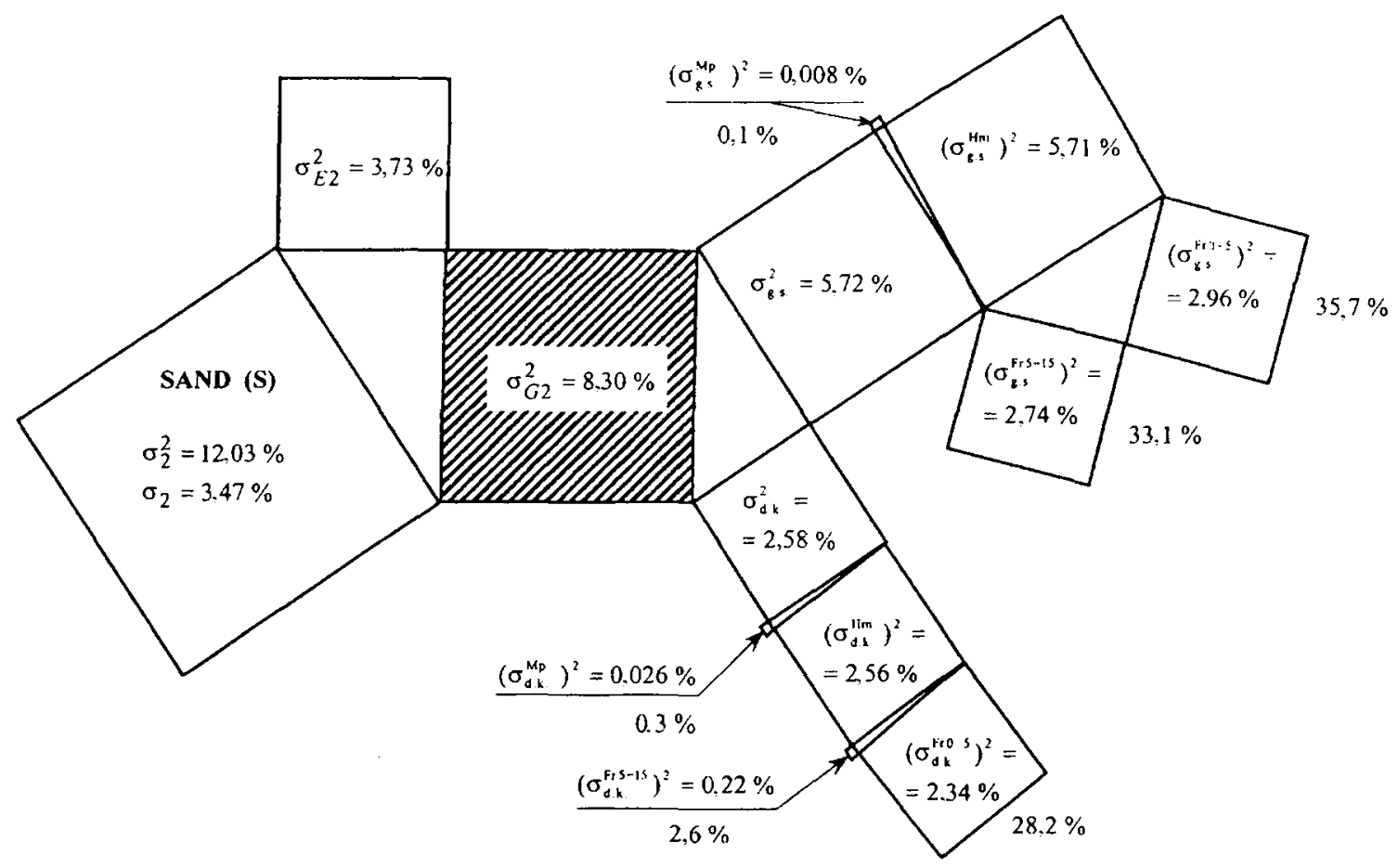

Fig 4. The diagram of technological factors importance influencing the variation of sand (S) quantity contained in asphalt concrete mixture produced from hot mineral materials of fractions of $0-5 \mathrm{~mm}$ and $5-15 \mathrm{~mm}$ as well as cold mineral powder weighed in the same dosing equipment in sampling action asphalt concrete mixing plant 


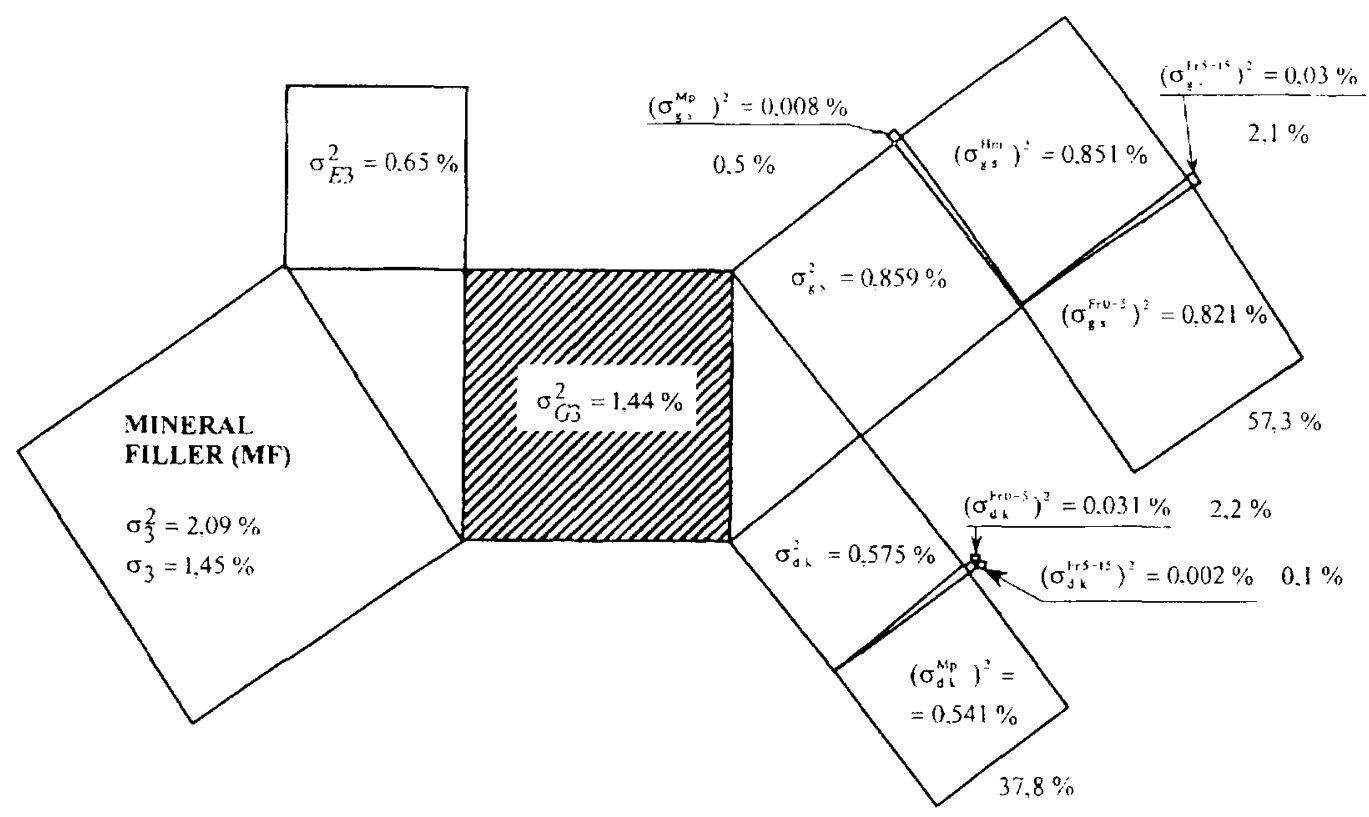

Fig 5. The diagram of technological factors importance influencing the variation of mineral filler (MF) quantity contained in asphalt concrete mixture produced from hot mineral materials of fractions of $0-5 \mathrm{~mm}$ and $5-15 \mathrm{~mm}$ as well as cold mineral powder weighed in the same dosing equipment in sampling action asphalt concrete mixing plant

does not depend on the stability of grading of mineral powder $(0,5 \%)$ and dosing errors of fraction $5-15 \mathrm{~mm}$ $(0,1 \%)$.

When values of mathematical model (8) are changed, values of variance $\sigma_{G i}^{2}$ and the influence in percent of summands making it up change as well. When increasing homogeneity of asphalt concrete mixture composition, the parameters of those technological factors due to which values of variance $\sigma_{G i}^{2}$ increase shall be improved at first.

\section{Conclusions}

1. In most European countries as well as in Lithuania asphalt concrete mixture is produced following the traditional technology in which the dried and heated mixture of original mineral materials is sieved into 3-5 hot fractions through technological sieves of asphalt concrete mixing plant, which are dosed in one bin by summing the mass of their portions. The main objective of sieving technological operation is to obtain purer and more homogeneous hot fractions than original mineral materials of analoguous size is not achieved or only partially achieved.

2. The grading of hot fractions is mostly worse (they are more contaminated with by-grains and are not homogeneous due to high segregation) than the grading of original cold mineral materials. Hot fractions of $0-5 \mathrm{~mm}$ sieved in asphalt concrete mixing plants are contaminated with grains larger than $5 \mathrm{~mm} \mu_{i j}=5,8 \%$ (from 0,94 to $13,72 \%$ ) and mineral filler finer than $0,071 \mathrm{~mm}$, $\mu_{i j}=9,8 \%$ (from 6,22 to $13,37 \%$ ) on average. Hot fraction of $5-15 \mathrm{~mm}$ is contaminated with grains finer than
$5 \mathrm{~mm} \mu_{i j}=16,8 \%$ (from 4,59 to $32,76 \%$ ) on average. In finer than $5 \mathrm{~mm}$ its grains there are $\mu_{i j}=1,4 \%$ of mineral filler (from 0,20 to $3,00 \%$ ) on average, the quantity of which shall be taken into account when finally dosing materials.

3. Variation of grading of finally dosed mineral materials and their dosing errors make up the largest part $\sigma_{G i}^{2}$ of variance $\sigma_{i}^{2}$ of asphalt concrete mixture mineral components quantity which depends on the production technology. Variance $\sigma_{G i}^{2}$ of crushed stone quantity in asphalt concrete mixture is mostly influenced by dosing errors $(57,5 \%)$ and stability of grading $(23,7 \%)$ of hot fraction of 5-15 mm sieved through technological screens of asphalt concrete mixing plant. Variance $\sigma_{G i}^{2}$ of sand quantity depends by $35,7 \%$ on the stability of grading of fraction $0-5 \mathrm{~mm}$ and by $33,1 \%$ on the stability of grading of fraction $5-15 \mathrm{~mm}$ as well as by $28,2 \%$ on the dosing errors of fraction $0-5 \mathrm{~mm}$. Almost more than half of variance $\sigma_{G i}^{2}$ of mineral filler quantity depends on the stability of grading of fraction $0-5 \mathrm{~mm}(57,3 \%)$ and by $37,8 \%$ on dosing errors of mineral powder.

4. When reducing the value of variance $\sigma_{G i}^{2}$ which depends on the production technology of asphalt concrete mixture,

- equipment reducing segregation of materials in section of hot fractions bin could be used;

- mineral powder could be dosed by a separate dosing unit or technological means by reducing their dosing errors in essence;

- the actual productivity of asphalt concrete mixing plant could not be reduced more than optimal (nominal); 
- condition of technological sieves could be periodically checked and in case they are damaged, shall be replaced by new screens;

- the same slightly changing quantity of hot fractions in bin section could be maintained during the working shift and they should not pour over the partitions of the bin;

- the work could be carried out as long as possible by avoiding frequent stopping of the equipment;

- grading of hot fractions sieved through technological screens could be controlled more frequently, and accordingly the quantity of all finally dosed mineral materials could be optimised by using the methodology developed by us [46];

- compliance with asphalt concrete mixture production technological regulations and work discipline could be guaranteed.

\section{References}

1. Roberts F. L., Mohammad L. N., Vang L. B. History of hot mix asphalt mixture design in the United States. Journal of Materials in Civil Engineering. July / August 2002, Vol 14, No 4, p. 279-293.

2. Sakharov P. E. Methods of designing of asphalt concrete mixtures. Transport and highways in the cities (Транспорт и дороги города), 1935, No 2(7), р. 23-26 (in Russian).

3. Jones Lee. Recent developments in coating plant technology. Quarry management, 1986, 13, No 10, p. 25-30.

4. Deshpande V. S., Cebon D. Uniaxial experiments on idealized asphalt mixes. Journal of Materials in Civil Engineering. 2000 Aug., Vol 12, No 3, p. 262-271.

5. Li G., Li Y., Metcalf J. B., Pang S.-S. Elastic modulus prediction of asphalt concrete. Journal of Materials in Civil Engineering. 1999, Aug., Vol 11, No 3, p. 236-241.

6. Romero P., Masad E. Relationship between the representative volume element and mechanical properties of asphalt concrete. Journal of Materials in Civil Engineering, 2001, Jan/Feb., Vol 13, No 1, p. 77-84.

7. Daniel J. S., Kim Y. R. Laboratory evaluation of fatigue damage and healing of asphalt mixtures. Journal of Materials in Civil Engineering, 2001, Nov./Dec., Vol 13, No 6, p. $434-440$.

8. Lee H.-I., Daniel I. S., Kim Y. R Continuum damage mechanics - based fatigue model of asphalt concrete. Journal of Materials in Civil Engineering, 2000, May, Vol 12, No 2, p. 105-112.

9. El Hussein H. M., Abd El Halim A. O. Differential thermal expansion and contraction: a mechanistic approach to adhesion in asphalt concrete. Canadian Journal of Civil Engineering, 1993, June, Vol 20, No 3, p. 366-373.

10. Yue Z. Q., Svec O. J. Effects of tire - pavement contact pressure distributions on the response of asphalt concrete pavements. Canadian Journal of Civil Engineering, 1995, Oct., Vol 22, No 5, p. 849-860.

11. Selvadurai A. P. S., Au M. C., Phang W. A. Modelling of low-temperature behaviour of cracks in asphalt pavement structures. Canadian Journals of Civil Engineering, 1990, Oct., Vol 17, No 5, p. 844-858.
12. El Hussein H. M., Kim K. W., Ponniah J. Asphalt concrete damage associated with extreme low temperatures. Journal of Materials in Civil Engineering, 1998, Nov, Vol 10, No 4, p. 269-274.

13. Baig M. G., Al-Abdul Wahhab H. I. Mechanistic evaluation of hedmanite and lime modified asphalt concrete mixtures. Journal of Materials in Civil Engineering, 1998, August, Vol 10, No 3, p. 153-160.

14. Al-Suleiman T. J., Obaidat M. T., Abdul-Jabbar G. T., Khedaywi T. S. Field inspection and laboratory testing of highway pavement rutting. Canadian Journal of Civil Engineering, 2000, Vol 27, p. 1109-1119.

15. Koroliov I. V. Ways of economy of bitumen in road construction (Пути экономии битума в дорожном строительстве). Moscow: Transport, 1986. 149 p. (in Russian).

16. Ribjev I. A. Asphalt concrete (Асфальтовые бетоны). Moscow: Visšaja škola, 1969. 400 p. (in Russian).

17. Koganzon M. S., Jakovlev I. M. Theory and methods of calculation of non-rigid road pavements. Science and engineering in road building (Наука и техника в дорожной отрасли), 2000, No 4 (15), p. 22-23 (in Russian).

18. Bakhtrakh G. S. Model of estimation of the non-rigid pavement service life. Science and engineering in road building (Наука и техника в дорожной отрасли), 2002, № 2 (21), p. 17-20 (in Russian).

19. Pečionyj B. G. Bitumens and bitumen compositions. (Битумы и битумные композиции). Moscow: Chimija, 1990. 256 p. (in Russian).

20. Barinov E. N., Loukashevich V. N. Two phases asphalt concrete mix production. Science and engineering in road building (Наука и техника в дорожной отрасли), 2000, No 2 (13), p. 9-11 (in Russian).

21. Melik-Bogdasaarov M. S., Gioev K. A., Melik-Bogdasarov N. A., Kuznecov M.M. Performence of asphalt concrete pavements by vibrocast method. Science and engineering in road building (Наука и техника в дорожной отрасли). 1997, No 3 (3), p. 9-11 (in Russian).

22. Vasiliev A. P. Reasons of rutting on pavements and ways of rut elimination. Science and engineering in road building (Наука и техника в дорожной отрасли). 1999, No 2(9), p. 6-9 (in Russian).

23. Bakhrakh G. S. Reclaiming of flexible pavements and road surfacings. Science and engineering in road building (Наука и техника в дорожной отрасли). 1998, No 3 (6), p. 18-21 (in Russian).

24. Gorelyshev N. V. It is necessary to perfect the asphalt concrete. Science and engineering in road building (Наука и техника в дорожной отрасли). 1998, № 2 (5), р. 14-16 (in Russian).

25. Kretov V. A., Kramer E. L., Rudenskij A. V. Reflected fracturing in asphalt pavements. Science and engineering in road building (Наука и техника в дорожной отрасли). 1998, No 1, p. 3-6 (in Russian).

26. Kirjukhin G. N., Jumashev V. M., Sokalskaja M. B. Laying of the uniform top dressing. Science and engineering in road building (Наука и техника в дорожной отрасли). 1998, No 1 (4), p. 13-15 (in Russian).

27. Orlovskij V. S. Estimation of thickness, deflection and crack resistance of road pavement layers. Science and engineer- 
ing in road building (Наука и техника в дорожной отрасли). 1997, No 2 (2), p. 14-15 (in Russian).

28. Leonovič I. I., Shumchik K. F., Koloskova I. V. Maitenance of stability properties of bitumens in an asphalt concrete. Automobile roads (Автомобильные дороги). 1989, No 4, p. 15-16 (in Russian).

29. Varenko V. A. Road composite materials. Structure and mechanical properties (Дорожные композитные материалы. Структура и механические свойства). Under edition. I. I. Leonovič). Minsk: Nauka i technika, 1993. 246 p. (in Russian).

30. Rokas S., Statistical control of quality in road construction (Статистический контроль качества в дорожном строительстве). Moscow: Transport, 1977. 152 p. (in Russian).

31. Puodžiukas V., Pakalnis A. Determination of seasonal factors for structural condition values of bituminous pavements. Journal of Civil Engineering and Management. 2002, Vol VIII, No 2, p. 133-137.

32. Petkevičius K., Sivilevičius $H$. The substantiation of demanded service properties of highway asphalt concrete covers. Transport Engineering (Transportas). 2000, Vol XV, No 4, p. 184-195 (in Lithuanian).

33. Čygas D., Laurinavičius A. The main problems of using asphalt concrete mixtures for pavements of automobile roads in town streets. City development and road. Supplement of journal „Civil Engineering“" (Miesto plètra ir keliai. Mokslo žurnalo „Statyba“ priedas). 2000, p. 20-26 (in Lithuanian).

34. Borisov V. A. Technological accuracy asphalt concrete plants and methods of its increase (Технологическая точность асфальтобетонных заводов и методы ее повышения). Saratov: Izdatelstvo Saratovskogo universiteta, 1975. 159 p. (in Russian).

35. Bunkin I. F. Automation of asphalt concrete production management. Summary of the research report presented for habilitation (Автореферат диссертации на соискание ученой степени доктора технических наук). Moscow, 2002. 33 p. (in Russian).

36. Guideline of construction R 35-01. Asphalt concrete and grit cover of automobile roads (Statybos rekomendacijos
R 35-01. Automobiliu keliu asfaltbetonio ir žvyro dangos) Vilnius: LAKD, 2001. 117 p. (in Lithuanian).

37. LST 1719: 2001. Mineral materials for roads. Technical requirements (Mineralinès automobilių kelių medžiagos ir jų mišiniai. Techniniai reikalavimai). Vilnius: Lietuvos standartizacijos departamentas, 2001. 7 p. (in Lithuanian).

38. LST EN 12591: 2000. Bitumen and bituminous binders specifications for paving grade bitumens (Bitumas ir bituminiai rišikliai. Kelių bitumų techniniai reikalavimai). Vilnius: Lietuvos standartizacijos departamentas, 2000. 17 p. (in Lithuanian).

39. Sivilevičius $\mathrm{H}$. Theoretical principles and experimental data to identify stability of asphalt concrete components in finally dosed mineral materials. Transport, 2002, Vol XVII, No 1, p. 19-29 (in Lithuanian).

40. Zhang I. Keys to success in drum mix plant market in southeastern states. News CMI corporation, Fall 1996, p. 18-23.

41. Kohler G., Kott W., Mohmeyer H., Eumann H.-G., Schilder G., Kiselski I. Erhöhte Zugabe von Asphaltgranulat. Die Asphaltstrasse, 1986, No 8, S. 455-463 (in German).

42. Hanzik V., Bukač $M$. Zkušenosti se znovuužitím n. p. PSVS. Dny nové techniky. Nové směry ve znovuužiti starých asfaltových směsi. Přispěvky domácích účastníku. Poděbrady, Libodřice, Běchovice, Bradlec. 1988.09.28-29, s. 35-53 (in Czech).

43. Erhardt H., Neumann G. Technische Aspekte zur Wiederverwendung von Asphait. Strasse und Autobahn. 1985, Vol 36, No 7, S. 269-273 (in German).

44. Evaluation of construction control procedures. Interim report. National Cooperative Highway Research Program: Report 34. Highway Research Board, 1967. 117 p.

45. Akishin I. P. Features of selection and application of technical means for materials and works quality control in road construction. Science and engineering in road building (Наука и техника в дорожной отрасли). 1997, No 1 (1), p. 9-11 (in Russian).

46. Sivilevičius H., Podviezko V. Conditional optimization mathematical model of the asphalt concrete mixture grading. Journal of Civil Engineering and Management. 2002, Vol VIII, No 2, p. 125-132. 